Marek Potkány ${ }^{l}$, Marek Debnár ${ }^{2}$, Miloš Hitka ${ }^{3}$, Miloš Gejdoš ${ }^{4}$

\title{
REQUIREMENTS FOR THE INTERNAL LAYOUT OF WOODEN HOUSE FROM THE POINT OF VIEW OF ERGONOMICS CHANGES
}

\begin{abstract}
A basic need of every responsible man is to provide for own housing with the continual increase of world population energy consumption is growing continually as well and in parallel there is an increase in $\mathrm{CO} 2$ emissions. Buildings during their lifetime use approximately $40 \%$ of energy, while its operation concerning heating and cooling counts for $60-70 \%$ of this consumed energy. The most suitable solution means building houses with low energy demands which do not harm the environment Therefore the preferred solution has become to build houses with low-energy houses not burdening the environment. The aim of this chapter is to present the basic aspects and advantages of wood buildings as well as their requirements for the internal layout from the point of ergonomics changes. We can state that based on findings and research, that the current generation of people has significantly higher height and weight proportions. Based on linear regression equations we define the magnitude of secular changes for men and women. The change represents a $1.55 \mathrm{~mm}$ body height increase for men and $0.5 \mathrm{~mm}$ for women per year.
\end{abstract}

Key words: wooden houses, preferences marketing, product value

\section{Introduction}

Housing is a basic human need, which is in the hierarchy of human needs included very high. It can be combined with the need to sleep a family of security and physical security. In recent years, with economic growth it increases the share of building production. People are increasingly addressing the problem of their housing by procuring a family home. Due to a certain level of environmental thinking, the share of construction increases in the given sector in relation to the environment. An important point of view is energy and the environmental style of housing. Lately, the countryside perks with building activity and we can an increased interest in building family houses. Accepting the targets of 20/20/20 of the Europe 2020 strategy we obliged to cut down gradually energy consumption, $\mathrm{CO} 2$ production and to increase the ratio of renewable energy sources. Buildings currently produce $1 / 3$ of world production of $\mathrm{Co} 2$ and consume $40 \%$ of world energy production, while the heating

1Faculty of Wood Sciences and Technology, Technical University in Zvolen, T.G. Masaryka 24, 96053

Zvolen, Slovakia. E-mail: potkany@tuzvo.sk

2 Faculty of Wood Sciences and Technology, Technical University in Zvolen, T.G. Masaryka 24, 96053

Zvolen, Slovakia. E-mail: xdebnar2@is.tuzvo.sk

3 Faculty of Wood Sciences and Technology, Technical University in Zvolen, T.G. Masaryka 24, 96053

Zvolen, Slovakia. E-mail: hitka@tuzvo.sk

4 Faculty of Wood Sciences and Technology, Technical University in Zvolen, T.G. Masaryka 24, 96053

Zvolen, Slovakia. E-mail: gejdos@tuzvo.sk 
portion makes up $60 \%$. Therefore, the preferred solution has become to build houses with low-energy houses not burdening the environment. In this way the building industry can contribute to the better use of limited resources, saving energy and decreasing emissions. Wood is the only renewable resource which we have and are able to provide repeatedly from own resources. The problem is that almost $35 \%$ of this raw material is exported and therefore we lose potential to increase added value resulting from its processing. A partial solution may be to support building energy efficient houses based on wood which guarantee savings on heat, ecology of their production and further use. The construction of low energy houses as for masonry or timber constructions using renewable sources of energy for heating and water heating are becoming the favoured solution. Wooden buildings in recent years are experiencing a boom in the Slovak house market. Their popularity is growing and every 10th house built in Slovakia has a wood-based structure. In Slovakia it can be estimated that wood-based buildings account for less than $10 \%$ of the new construction. In the Czech Republic, it is almost 18\%, more common in the UK - 20\%, in Austria - 35\%, in Germany - 49\%, the United States and Canada - 80\%, in Sweden and the Nordic countries - more than $80 \%$. In Austria, in the form of national programs, efforts are made to make the proportion of timber construction increase to $80-90 \%$ [1].

This chapter focus on the present the basic aspects and advantages of wood buildings as well as their requirements for the internal layout from the point of ergonomics changes and also determination of basic requirements under the Building Law and a study on the typology of buildings in terms of technical and technological properties. It creates requirements for the spatial requirements of living spaces that are part of the presentation of the given chapter.

Of the basic requirements, we are focusing in particular on energy performance buildings according to EN 15459 [2]. Table 1 presents an overview of energy classification according to STN 730540 [3]. It is valid that every building approved after 1.1.2016 must have an energy certificate of class A1.

Table 1. Energy classes of global indicator (primary energy)

\begin{tabular}{|c|c|c|c|c|}
\hline \multirow{2}{*}{$\begin{array}{c}\text { Building category global primary } \\
\text { energy indicator } \\
\left(\mathbf{k W h} / \mathbf{m}^{\mathbf{2}} \mathbf{a}\right)\end{array}$} & \multicolumn{4}{|c|}{ Energy classes of global indicator } \\
\cline { 2 - 5 } & $\begin{array}{c}\mathbf{A 0} \\
\text { From } \\
1.1 .2021\end{array}$ & $\begin{array}{c}\mathbf{A 1} \\
\text { From } \\
1.1 .2016\end{array}$ & $\begin{array}{c}\text { B } \\
\text { To 31.12.2015 }\end{array}$ & \multirow{2}{*}{$\mathbf{C}$} \\
\hline Family house & $\leq 54$ & $55-108$ & $109-216$ & $161-324$ \\
\hline Flats of house & $\leq 32$ & $33-63$ & $64-126$ & $127-189$ \\
\hline
\end{tabular}

Source: [51] 
Of course, the trend towards lowering the energy performance of buildings is particularly positive from an ecological point of view, but causes increased investment costs for the investor. It is beneficial for the investor to be analysed the most appropriate lifecycle methods are used to objectively evaluate investment and its payback from a comprehensive perspective. For ages a man has had a positive and natural attitude towards wood. Processing wood for building purposes and its liquidation presents energetically and ecologically undemanding process. Wooden houses have excellent thermally insulating properties compared to other materials, formation of moulds and allergens is excluded. During realisation of the house there is a dry process of construction, ecology and time of its realisation a great competitive advantage.

If we focus on energy consumption then for masonry new buildings which meet Slovak building and technical regulations, the energy consumption for heating moves within the range of $70-150 \mathrm{kWh} / \mathrm{m}^{2} /$ year. The trend of continuous increase in energy prices, each addressed the question of the potential savings. The solutions are energy efficient wooden houses (EEWH) which we can divide into:

- low-energy houses with heat consumption to $\max 50 \mathrm{kWh} / \mathrm{m}^{2} /$ year,

- passive house ( $\max 15 \mathrm{kWh} / \mathrm{m}^{2} /$ year),

- zero energy building ( $\max 5 \mathrm{kWh} / \mathrm{m}^{2} /$ year).

There exist several types of buildings which actively cope with the requirements of minimising the energy consumption of their operations. Tywoniak [4] declares that, globally these are understood as so called energy effective houses (EED), which include low energy houses (NED), energy passive houses (EPD), energy self-sufficient houses (END), energy independent autarkic houses (EAD) as well as plus energy houses. In this article we will closely focus only on low energy and energy passive houses [5]. Division of these buildings according to heat consumption is presented in Figure 1.

Ruziak et al. (2017) and Igaz (2014 and 2010) [6, 7, 8], deals with the given issue in their works. The ecological aspect is also very important. To what extent and to what extent is it necessary to deal with the construction of a house in terms of ecological impact, we refer to ISO 14040 and $14044[9,10,11]$ which show how to use the Life Cycle Assessment (LCA) analysis to assess the environmental impact of a family house over the life cycle of the building. All appliances and equipment, with which it comes into human contact, are adapted to the measurements of the human body. Products would not meet the needs of its users if they did not respect these dimensions. Therefore, industrial production relies on anthropometric measurements as a key factor in the production of any product. Also in the wood working industry, it is necessary to take into account the height, weight, length of human limbs, reach and possibilities of human movement, because these factors influence not only the creation 
of furniture but also the basic requirements for living space. Many studies confirm the secular growth of the anthropometric measurements of the adult population $[12,13]$.

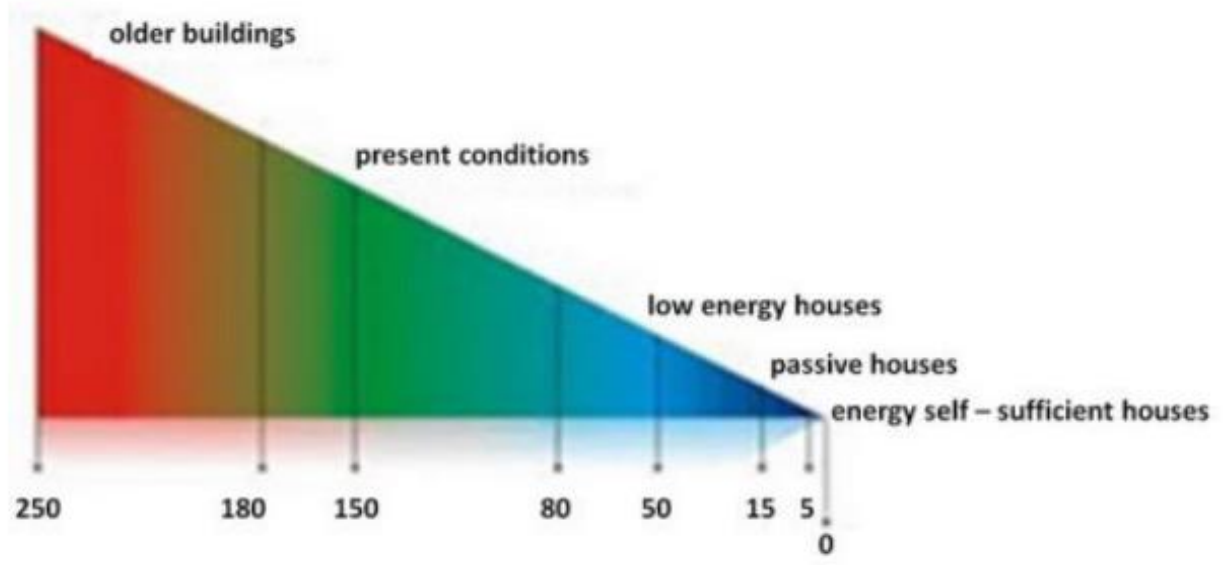

Fig. 1. Division of buildings according to heat consumption ( $k W h / m 2 / p e r$ annum) Source: [52]

Anthropometrics is the science concerned with the measurement of humankind. Inevitably it is bound up with statistics, as people vary considerably in most dimensions. Anthropometrics is of crucial importance to architects as the ultimate basis of the design of most buildings must be the size of the people using them. When surveys are taken of adult males, for example, they show a normal distribution curve: the traditional statistical bell shape (figure 2). This shape is totally definable by the two parameters, mean and standard deviation (SD). For the purposes of the architect, the standard deviation can be taken as the difference from the mean within which 84 per cent of the population are included. The percentage included is called the 'percentile', and it has become accepted (with certain exceptions) that designers generally seek to accommodate those within the band between the 5th and 95th percentile - that is, they do not attempt to satisfy the last 10 per cent of the people. In each case it is the job of the architect to decide whether in fact this will be acceptable. 


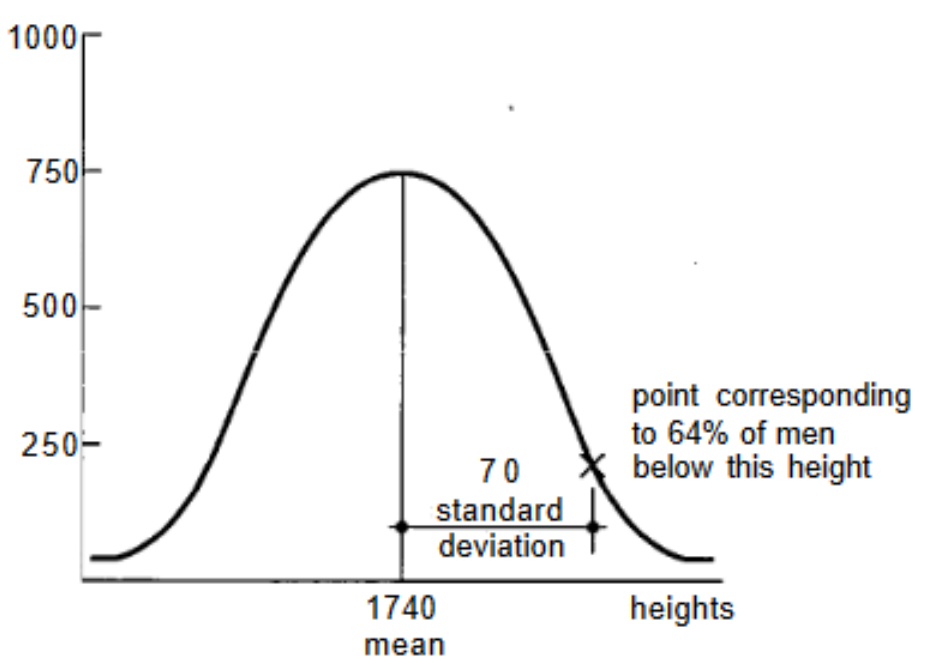

Source: [14]

Fig. 2. The traditional statistical bell shape

Giurazza et al. (2013), Torimitsu (2016) and Kobusingye et al. (2005) [15, 16, 17] states that it is obvious that environmental and geographic conditions food intake and lifestyle affect anthropometrics measurements. Every community needs to have essential information about anthropological criteria from its population. These data provide basic information about physical characteristics of population that is necessary and helpful in industrial design, surgery, forensic and sport sciences. One of the most important usages of the anthropological measurements is determination of race, age and stature of unknown bodies. Torimitsu declarate that there are different kind of bones in each body and most of them can be used for this purpose. Gharehdaghi et al. (2018) [18] states that in identification of unknown bodies, the basic anthropometric data of every society is required, and without them the identification would not be reliable. Human body parts for pattern making presents Balakumar (2010) [19] in his study (figure 3). 


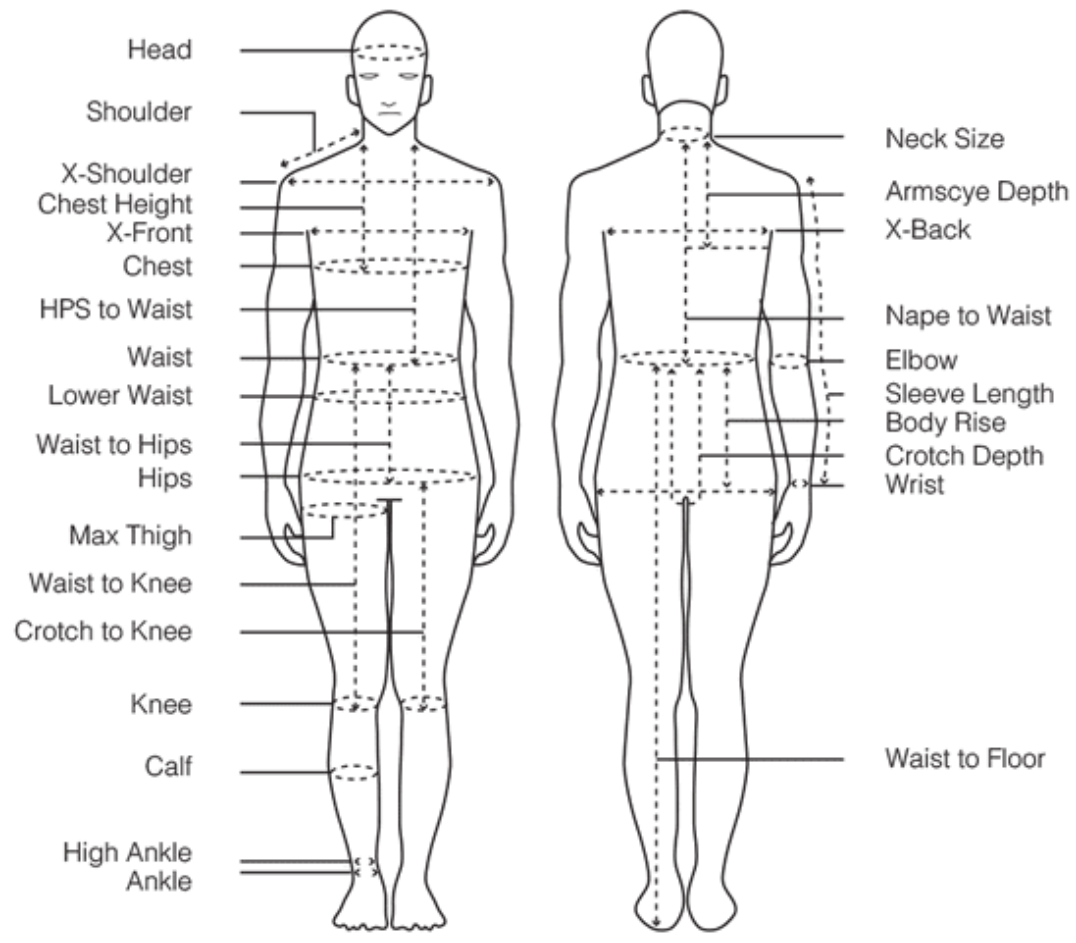

Fig. 3. Human body parts for pattern making

Source: [19]

\section{Methodology}

When dimensioning a living space and creating optimal conditions there is a common aspect ratio of the size of a person whose needs are provided in these buildings. Therefore, it is essential to take into account the anthropological dimensions of the human body and the resulting spatial needs necessary for the performance of housing-related activities. Significant details of the proportions come from the Pythagoras, the so-called "Pythagoras Triangle". Contains all harmonic interval proportions of the golden ratio. The golden ratio is a cosmic law, also manifested in nature, for example, in plant anatomy, in chemistry in crystalline structures and composition of compounds, in astronomy in star and planet positions.

The golden ratio - the ideal two-part ratio - the line is divided into two parts so that the ratio of the larger part to the smaller part of the line is the same as the ratio of the whole line to the larger part. In order to get to the method of calculating the gold ratio, it is necessary to explain what we mean by the term golden ratio. If we divide the line $\mathrm{AB}$ length and point $\mathrm{C}$ into two parts $\mathrm{x} \mathrm{a}(\mathrm{a}-\mathrm{x})$ so that the ratio of the lengths 
of the larger part $\mathrm{x}$ to the smaller part $(\mathrm{a}-\mathrm{x})$ equals the ratio of the length of the line and the larger part $\mathrm{x}$ to pay the relation 1 , shown in figure 4 .

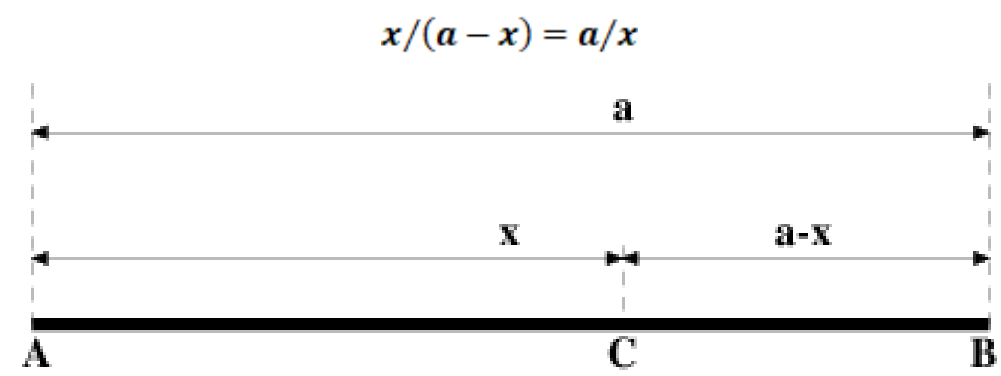

Fig. 4. Essence of golden ratio

Source: [20]

Then we can say that we have constructed the golden ratio (point C) of the line $\mathrm{AB}$ and the ratio a:x, resp. $\mathrm{x}$ : $(\mathrm{a}-\mathrm{x})$, we call the golden ratio. This ratio was denoted by American mathematician Mark Barr as the letter $\varphi$, according to the initial letter of the name of the most famous ancient Greek sculptor Feidia, who used the golden rust in his works. We can easily determine the value. Select a line size of $\mathrm{a}=1$ and reach the golden section equation:

$$
x /(1-x)=1 / x_{\ldots} x^{2}+x-1=0 \ldots x_{1}=((-1+\sqrt{5}) / 2)=0.61803=1 / x_{1}=1.61803=\varphi
$$

Golden ratio in art and architecture - a composite principle that harmoniously addresses the relationships of the individual components of the work, so as to get closer to the ideal of beauty as close as possible. The construction of the human body itself is the culmination of the art of nature that the architect is trying to understand. Especially in the Renaissance it was cultivated and maintained the opinion that the most beautiful are the units where golden ratio can be found. Teachers advised their paint apprentice to construct the body according to the golden cut. The aesthetics philosophers found a golden rust in the human body at a ratio of the lengths above the belt and below the belt. And these parts of the body can be redistributed to two parts in a ratio of 0.618: 1 . The degree of beauty of a certain figure is how much its proportions have been approached to average or, respectively, normal proportions. Creating an art decree or canon. The best known rule for the canon is the so-called "The Saint Andrew's cross" is the canon of the Roman architect Vitruvio, according to which the length of the upper limbs is equal to the height of the body, so that the human body can be drawn into a square, around the circle - the center is in the navel which became a natural center the so-called Vitruvian figure was used in the Renaissance by Leonardo da Vinci and Albrecht Dürer. Adolf Zeissing pronounced 
the golden rule as the law of proportionality. The golden rust applies to him for all body parts (even for the limbs), so the length of the forearm with the hand is to the length of the arm in the same ratio as the length of the entire upper limb to the forearm with the hand. Based on the principles of the golden cut and the Vitruvia concept, humanist Leonardo da Vinci created around 1490 in his sketch of the Canon of Proportions study according to the ideal proportions of the male body. A study called Canon of Proportions, Homo Vitruvius (figure 5).

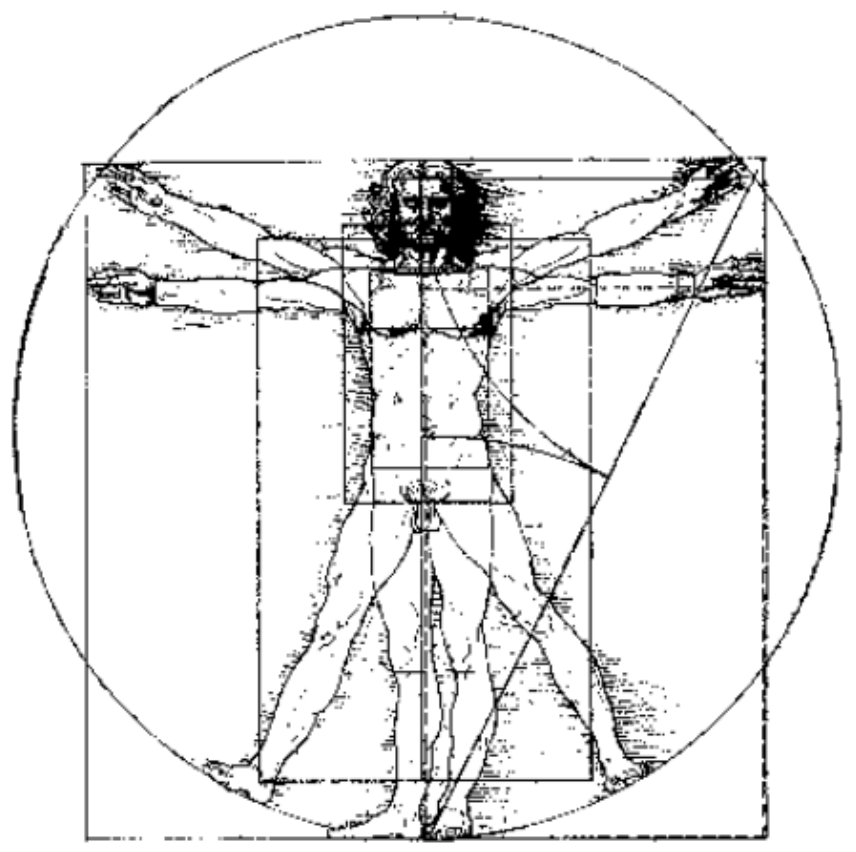

Fig. 5. Canon of Proportions, Homo Vitruvius

Source: [21]

It is a male ideal or the form of an ideal person. It is a drawing of man and his human body in the middle of a circle and a square. This drawing is derived from Vitruvius's papers dealing with geometry and human proportions. Architect Le Corbusier has developed the apprenticeship of proportions, which is built on the golden ratio and dimensions of the human body. Le Corbusier, in its modulus, features three proportional intervals of the human body. It was based on the known average height of "europan" - $1.75 \mathrm{~m}$ and divided this height according to the golden cut at three intervals [22]. Presented in figure 4 with values. Le Corbusier has brought these dimensions into virtually usable scale values of unlimited numeric values for space height definition [23]. 


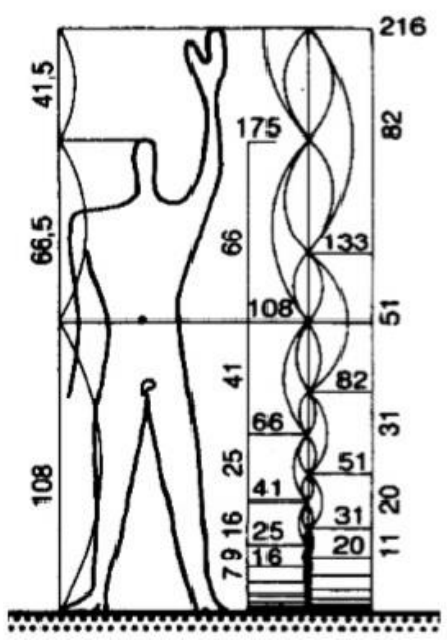

1. legs and drives - solar plexus (chest) $-108.2 \mathrm{~cm}$

2. solar plexus (chest) - head - $66.8 \mathrm{~cm}$

3. head - lifted hand with extended palm $-41.45 \mathrm{~cm}$

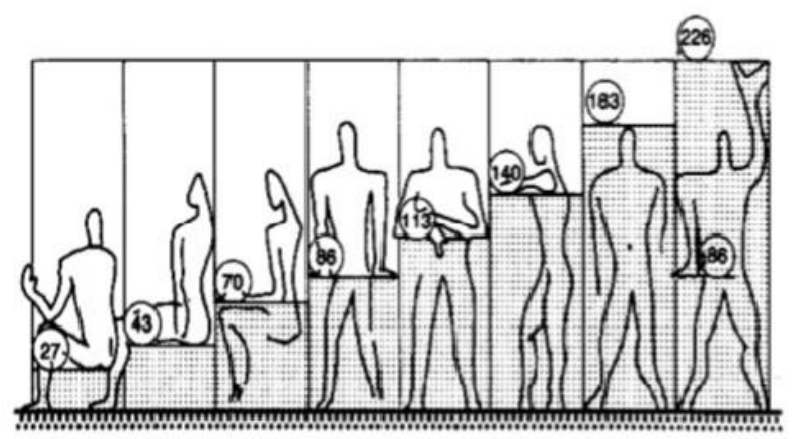

Fig. 6. Le Corbusier : Proportional figure - Modulor l'homme and its ergonomic applications

Source: [22]

Table 2. Average dimensions of the human body

\begin{tabular}{|c|c|c|c|c|c|}
\hline \multicolumn{3}{|c|}{ The height of the standing person } & \multicolumn{3}{|c|}{ The height of the sitting person } \\
\hline & \multicolumn{2}{|c|}{$\begin{array}{l}\text { Average } \\
\text { values } \\
(\mathrm{mm})\end{array}$} & & \multicolumn{2}{|c|}{$\begin{array}{c}\text { Average } \\
\text { values } \\
\text { (mm) }\end{array}$} \\
\hline & men & $\begin{array}{c}\text { wome } \\
\mathrm{n}\end{array}$ & & men & $\begin{array}{c}\text { wome } \\
n\end{array}$ \\
\hline Total body height & $\begin{array}{c}174 \\
0\end{array}$ & 1620 & Height of vertex head & 880 & 845 \\
\hline Max. reach of hands & $\begin{array}{c}221 \\
0\end{array}$ & 2030 & Height of eyes & 750 & 730 \\
\hline $\begin{array}{l}\text { Eye height above } \\
\text { the ground }\end{array}$ & $\begin{array}{c}161 \\
0\end{array}$ & 1500 & Height of the arms & 560 & 540 \\
\hline Height of the arms & $\begin{array}{c}141 \\
0\end{array}$ & 1310 & Table top height & 695 & 650 \\
\hline $\begin{array}{l}\text { Height of the } \\
\text { elbows }\end{array}$ & $\begin{array}{c}109 \\
0\end{array}$ & 1000 & $\begin{array}{l}\text { Height of the heel above the } \\
\text { seat }\end{array}$ & 230 & 230 \\
\hline $\begin{array}{l}\text { Wrists of running } \\
\text { arms }\end{array}$ & 810 & 760 & $\begin{array}{l}\text { Recommended heigh of the } \\
\text { seating surface }\end{array}$ & \multicolumn{2}{|c|}{430} \\
\hline Knees & 485 & 440 & $\begin{array}{c}\text { The height of the table top } \\
\text { above the seat }\end{array}$ & 280 & 260 \\
\hline
\end{tabular}

Source: [23]

Some average dimensions of the human body for male body height of $174 \mathrm{~cm}$ and for women $162 \mathrm{~cm}$ (with a possible standard deviation of $7 \mathrm{~cm}$ ) of standing and 
sitting figures are presented in Table 2. The proportional Modulor figure may have been proved quite instructive - Le Corbusier's original was based upon the average height of European people at the time $(175 \mathrm{~cm})$ and later adjusted to six feet $(183 \mathrm{~cm})$ - since it returned to the fact that rooms need to be based upon the measurement of the human body, best described in feet and inches. Still, Le Corbusier's Modulor system is rarely used, although it is regarded as a brilliant intellectual performance. The dimensions of the human body of the standing and sitting figure are presented in figure 7 .
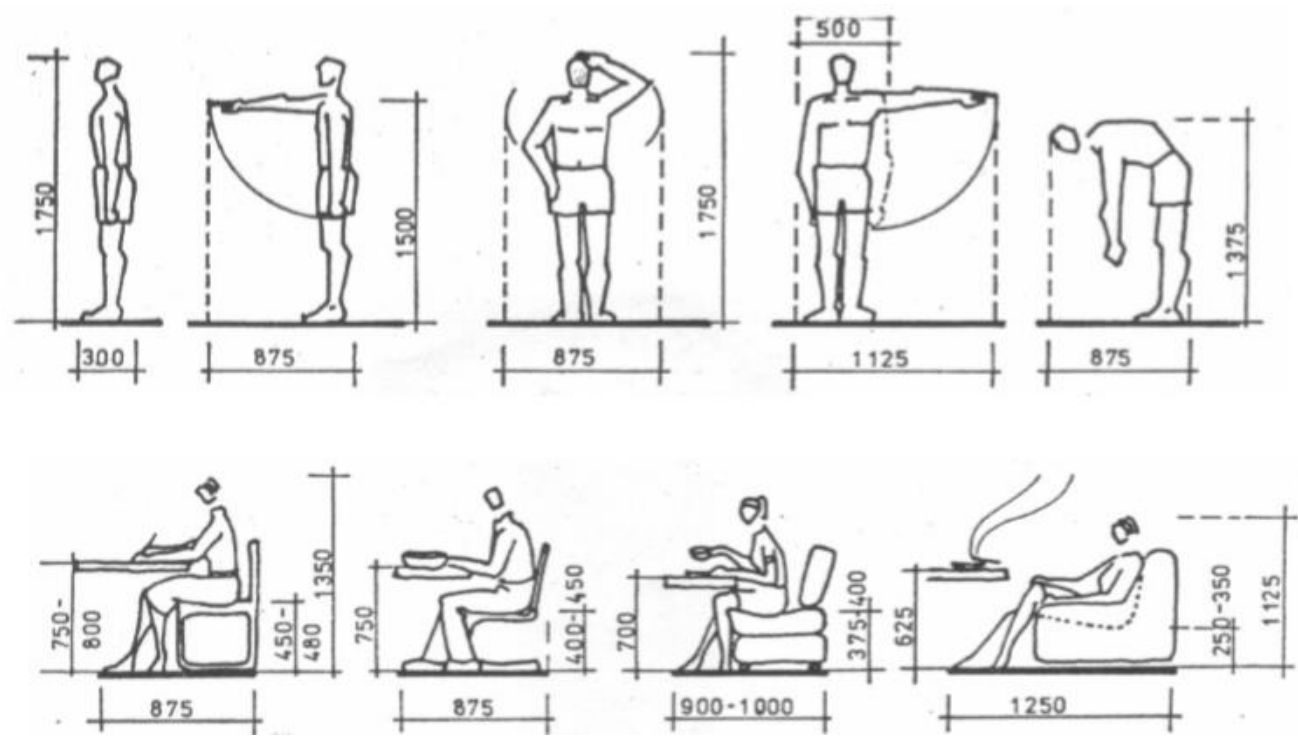

Fig. 7. The dimensions of the human body of the standing and sitting figure according to Corbusier

Source: [23]

It is obvious that at the time of changing the dimensions of the human body. It is due to lifestyle, company modernization, care, and so on. These changes are collectively called the secular trend. On the basis of previous research of authors Sedmák, Hitka, we can state that there is a secular growth trend in the adult population in Slovakia [24, 25]. We can regard the existence of a secular trend as a global phenomenon and this fact confirms the results of other foreign works and research $[[26,27,28,29,30,31,32]$. The current generation of men has significantly higher altitudes but also weight proportions and therefore BMI is increasing. We can justify this steep rise in the weight of men so that fashion trends recognize muscular and developed men more than before. In view of this, there is a research on the secular trend of an adult population in Slovakia. The experimental sample consists of the adult 
population of Slovakia, ie the population after reaching the age of adulthood from the point of view of the growth process of people (18 years and over). We use a direct survey technique to obtain data, so data is obtained by measuring selected anthropometric features (body height, bideltoid width of arms, etc.). We use an anthropometer to anthropometric body height measurement and pelvimeter to measure shoulder width. The data obtained is then processed and described using descriptive statistics tools and methods. The magnitude and variation of the measured values were characterized by Scheer by arithmetic mean, standard deviations, and coefficient of variation [33]. In anthropometric literature, there is a set of standardized dimensions and characters that can be accurately detected on the human body. Based on our experience and literature analysis, we present a selection of dimensions and features that can be used in hygienic and ergonomic practice, especially when designing the optimal spatial layout of the workplace and creating an optimal working environment. The empirical measurements of the values of selected anthropometric features of the current population were made in the years 1992-2016 on a sample of 789 men and 975 women aged 18-25 years coming from all over Slovakia. The data were obtained and compared with data from the Czechoslovak "Spartakiada" (sport demonstration activities) from 1980 and 1985 (619 men, 650 women). Consequently, we have computed descriptive statistics for respondent groups, such as arithmetic averages, standard deviations, medians, variance coefficients, variance, minimum and maximum values, quantum boundaries, coefficients of curvature, and slope coefficients. In the calculations, we focused on two main indicators - body height and body weight. Based on these indicators, we analysed the secondary character of the resulting from them BMI (body mass index - body mass index). We are able to consider this index (Equation 1) as an indicator of an individual's health if it is in its ideal and normal values ranging from 20.00 to 25.00 .

$$
B M I=\left(m / h^{2}\right)
$$

where: $m$-is body weight in kilos, $h^{2}-i$ s a square of height in meters.

We used the Student $\mathrm{t}$ - test and $\mathrm{F}$ - test the correlation of two variances to compare of the arithmetic averages of the values measured at different 2 periods. The two-choice test is based on zero hypotheses testing where we assume that two variables are equal to the second alternative where we assume the inequality of these variables.

$$
H_{0}: \mu_{1}=\mu_{2} \text { compared to alternative } H_{1}: \mu_{1} \neq \mu_{2}
$$

The STATISTICA 12.0 software (Statsoft, Inc. 2012) was used for all calculations. The tests were done at the level of significance $\alpha=5 \%$. The aim of this chapter is to present the basic aspects of low-energy houses $\mathrm{s}$ as well as their requirements for the internal layout from the point of ergonomics changes. To illustrate the impact, we will 
consider the reference structure whose specific characteristics have been determined by previous research. Based on the customer preference survey [34, 35, 36], we chose a representative house built by Atrium Ltd., designated the Jubileum Profi 116 (Figure 8 ), of a $116 \mathrm{~m}^{2}$ utility area [37]. The questionnaire survey showed that the greatest interest is for houses with a usable area between 101-120 $\mathrm{m}^{2}$, one storey, a saddle roof and a low energy standard. According to (STN 73 0540-2/Z1, 2016) [38] all new buildings in the A1 energy class must also have the thermal-technical properties to meet the relevant energy class (presented in Table 1) [39]. According to Ozel, (2012) this parameter influences the future operating costs and depends largely on the insulation thickness [40]. The basic layout and properties of the building components resulting from the thermo-technical properties we see on figure 9,10 and 11.

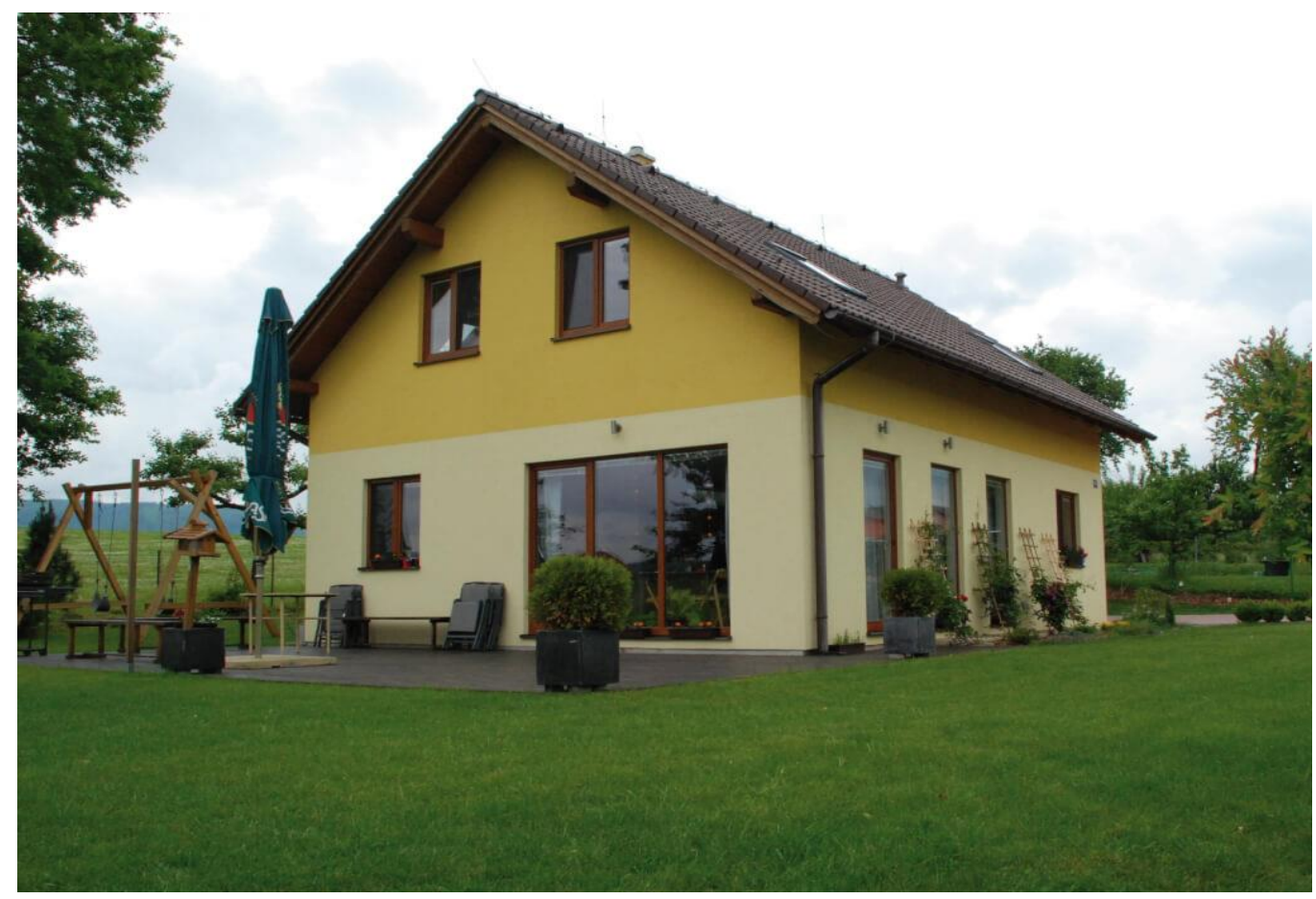

Fig. 8. House Jubileum Profi 116 from Atrium s.r.o.

Source: [37]. 


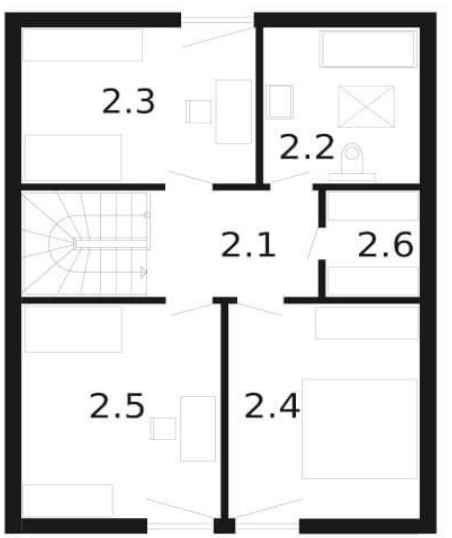

Vario Profi 116

2. NP

2.1 chodba

2.2 koupelna

2.3 pokoj

2.4 ložnice

2.5 pokoj

šatna

celkem
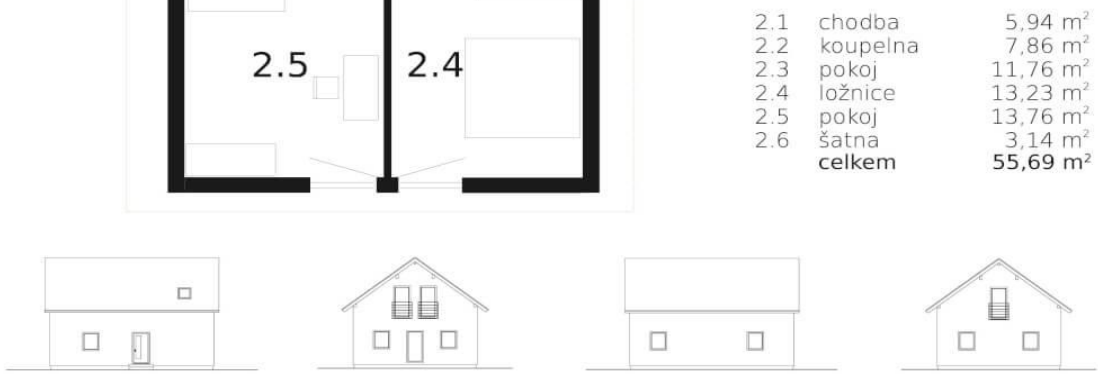

Fig. 9. Disposition of the house - ground floor

Source: [41].
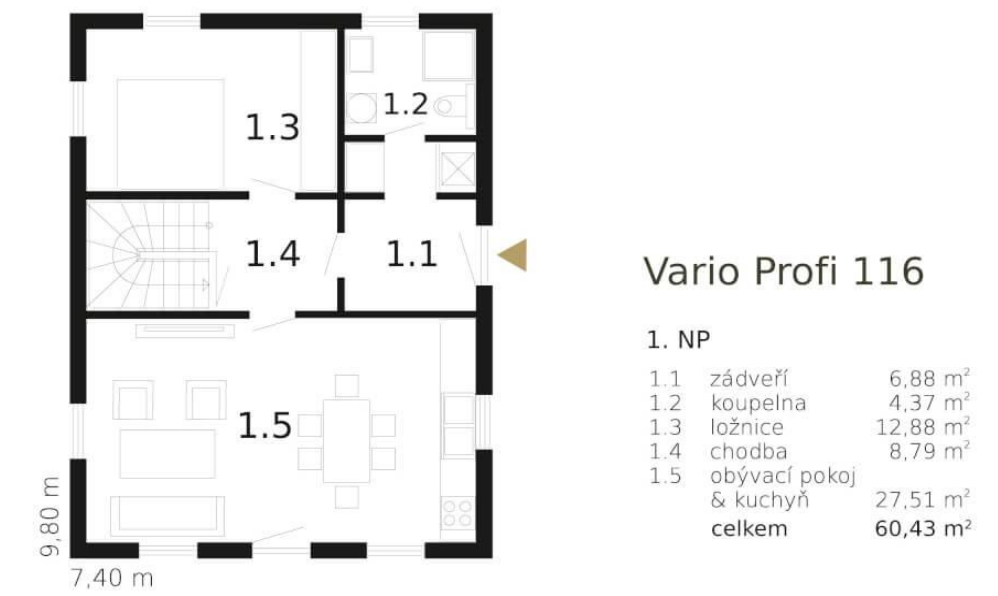

Source: [41].

Fig.10. Disposition of the house - 1st floor 

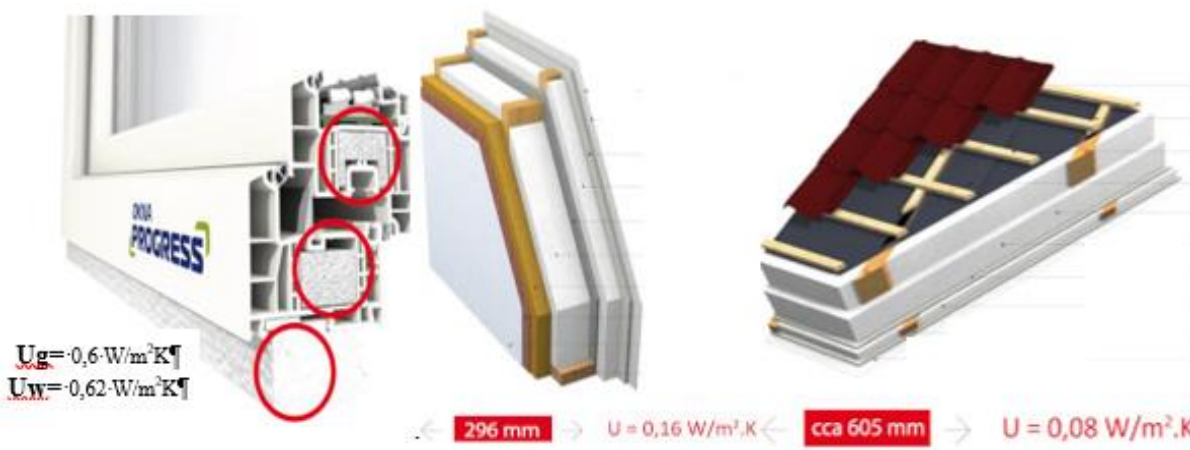

cca $605 \mathrm{~mm} \rightarrow U=0,08 \mathrm{~W} / \mathrm{m}^{2} \cdot \mathrm{K}$.

Fig. 11. Components of house (windows, walls and roof)

Source: [41].

At Table 3 we present all key property details and price calculation of this reference low-energy house from the study Debnár, Potkány, Lorincová, (2017) [42].

Table 3. Property details and Investment costs

\begin{tabular}{|c|c|c|}
\hline Location & \multicolumn{2}{|c|}{$\begin{array}{l}\text { Zvolen, Môt'ová City, Region of Banská } \\
\text { Bystrica, Slovakia }\end{array}$} \\
\hline Purchase Price & \multicolumn{2}{|c|}{$€ 169,654$} \\
\hline Price of land & $€ 42,000^{*}$ & $700 \times 60 € / m^{2}$ \\
\hline Price of base plate & $€ 9,062$ & $72,5 \times 125 € / \mathrm{m}^{2}$ \\
\hline $\begin{array}{l}\text { Price of timber house Jubileum } \\
\text { Profi } 116 \text { from Atrium s.r.o. }\end{array}$ & $€ 118,592$ & $116 \times 1,022 € m^{2}$ \\
\hline \multicolumn{3}{|c|}{ Construction details } \\
\hline Age & \multicolumn{2}{|c|}{ A new timber } \\
\hline No. of Bedrooms & \multicolumn{2}{|c|}{4} \\
\hline Structure & \multicolumn{2}{|c|}{ Panel system } \\
\hline Floor & \multicolumn{2}{|c|}{ Concrete and insulation system } \\
\hline Ceiling/Walls & \multicolumn{2}{|c|}{ Prefabricated wall (figure3) } \\
\hline Windows & \multicolumn{2}{|c|}{ Plastic window (figure3) } \\
\hline Cladding & \multicolumn{2}{|c|}{ Plaster } \\
\hline Roof & \multicolumn{2}{|c|}{ Bramac (figure 3) } \\
\hline Deck & \multicolumn{2}{|c|}{ Structure timber with insulation cladding } \\
\hline
\end{tabular}

Sources: [41].

\section{Results and discussion}

Changing anthropometric parameters of a person is often associated with the term secular trend. For the secular trend we can consider all the changes that occur in the development and growth of generations that follow. Exactly the term secular trend or secular changes mean the changes in the physical dimensions between the 
comparisons of past and present generations at the same age range. These changes do not occur suddenly but over a long-term development, but in one and the same territory. We can characterize it as all changes that are related to intergenerational differences in the same gender in both parents and children of the corresponding age categories. The main impacts are the health status of different individuals as well as their socio-economic conditions. We can claim that this trend has taken on a global character. In particular, it is responsible for changing the overall lifestyle - improving health care, increasing the quantity, quality and availability of food, mixing ethnicity and peoples, various psychosocial changes. Secular trend is best observed at the height of the character. The results of the previous research by authors Hitka et.al., (2017) [43] are contained in Table 4 and table 5 and figures 12 and 13.

The weight (not the length character measured in $\mathrm{kg}$ ) has a special position from the anthropometric data observed in both analysed male / female categories. We note that there was a change of $10.53 \%$ of the average weight in the male category and a weight increase of only $4.63 \%$ of the average weight in the female category. The height of men increased by $3.15 \%$ and for women by $1.76 \%$. BMI increased by $3.82 \%$ in the male category, but the BMI did not change for women. This research statistically demonstrates the existence of significant secular trends in the observed characteristics. The new generation of males, compared to older populations, is consistently characterized by better height growth combined with higher body weight and consequently higher BMI. In the female category, there is an increase in height and a corresponding increase in weight (but the BMI remains the same). The subsequent generation of men is higher and larger in size, and the generation of women is higher and slimmer. Based on linear regression equations, we can define the magnitude of secular changes for men in 1992-2016 (table 4, figure 12).

Table 4. Descriptive male's statistics in 1980-1985 and 1993-2016

\begin{tabular}{|c|c|c|c|c|c|}
\hline & \multicolumn{5}{|c|}{ Men 18-25 years (1980-1985) } \\
\hline & $\overline{\boldsymbol{x}}$ & K 5\% & K 95\% & $\mathrm{s}_{\mathrm{x}}$ & $\begin{array}{c}\text { T-test } \\
\text { p-level }\end{array}$ \\
\hline weight & 71.57 & 57.46 & 85.67 & 8.60 & 0.00000 \\
\hline height & 176.40 & 165.74 & 187.06 & 6.50 & 0.00000 \\
\hline BMI & 22.99 & 19.30 & 26.69 & 2.26 & 0.00000 \\
\hline & $\overline{5}$ Men 18-25 years (1993-2016) \\
\hline & $\overline{\boldsymbol{x}}$ & K 5\% & K 95\% & $\mathrm{S}_{\mathrm{x}}$ & $\begin{array}{c}\text { T-test } \\
\text { p-level }\end{array}$ \\
\hline & 79.11 & 61.00 & 100.00 & 12.26 & 0.00000 \\
\hline weight & 181.96 & 171.00 & 194.00 & 6.97 & 0.00000 \\
\hline height & 23.87 & 18.92 & 29.60 & 3.24 & 0.00000 \\
\hline
\end{tabular}

Source: [43] 
The change of one year represents a $0.1545 \mathrm{~cm}(1.55 \mathrm{~mm})$ body height increase and an increase in body weight of $0.3107 \mathrm{~kg}$. The third regression equation for men shows the dependence between time and BMI index the body mass index BMI increases by 0.0547 per year.

$$
\begin{aligned}
& \text { YEAR: Height: } y=-129.0934+0.1545 * x \\
& \text { YEAR: Weight: } y=-546.3349+0.3107 * x \\
& \text { YEAR: BMI: } y=-86.1719+0.0547 * x
\end{aligned}
$$

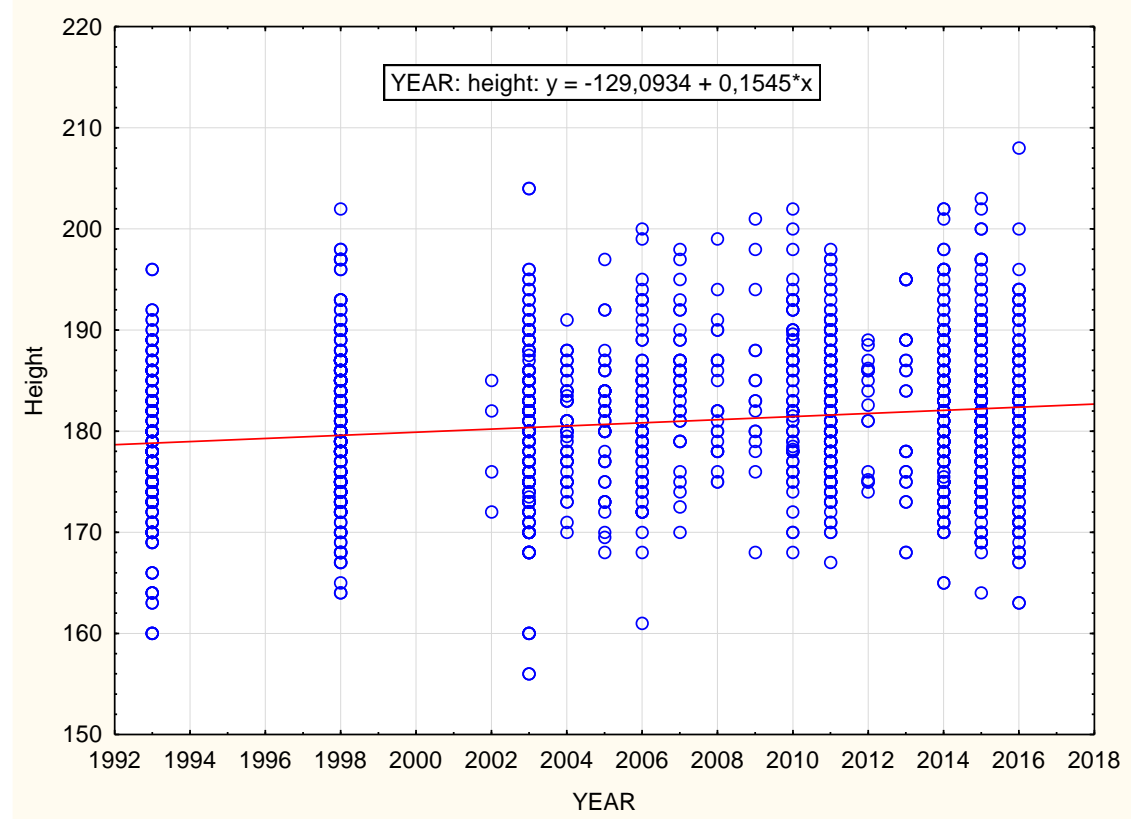

Source: [43]

Figure 12. Estimated height increase model in male category

Based on linear regression equations, we can define the results of secular changes in female category (table 5, figure 13). There is an increase in body height of $0.0463 \mathrm{~cm}(0.5 \mathrm{~mm})$ per year. The third regression equation for women shows the dependence between the number of years and the BMI index. The body mass index BMI increases by 0.0013 per year.

$$
\begin{aligned}
& \text { YEAR: Height: } y=74.431+0.0463 * x \\
& \text { YEAR: Weight: } y=7.6291+0.0258 * x \\
& \text { YEAR: BMI: } y=23.8454-0.0013 * x
\end{aligned}
$$


Table 5. Descriptive women's statistics 1980-1985 and 1993-2016

\begin{tabular}{|c|c|c|c|c|c|}
\hline & \multicolumn{5}{|c|}{ Women 18 - 25 years (1980-1985) } \\
\hline & $\overline{\boldsymbol{x}}$ & K 5\% & K 95\% & $\mathrm{s}_{\mathrm{x}}$ & $\begin{array}{c}\text { T-test } \\
\text { p-level }\end{array}$ \\
\hline weight & 57.17 & 45.04 & 69.31 & 7.40 & 0.00000 \\
\hline height & 164.71 & 155.04 & 174.39 & 5.90 & 0.00000 \\
\hline BMI & 21.31 & 17.35 & 24.73 & 2.25 & 0.00000 \\
\hline & \multicolumn{5}{|c|}{ Women $18-25$ years (1993-2016) } \\
\hline & $\overline{\boldsymbol{x}}$ & K 5\% & K 95\% & $\mathrm{s}_{\mathrm{x}}$ & $\begin{array}{c}\text { T-test } \\
\text { p-level }\end{array}$ \\
\hline & 59.82 & 48.00 & 77.00 & 9.24 & 0.00000 \\
\hline weight & 167.61 & 158.00 & 178.00 & 6.02 & 0.00000 \\
\hline height & 21.31 & 17.65 & 26.80 & 3.21 & 0.00000 \\
\hline BMI &
\end{tabular}

Source: [43]

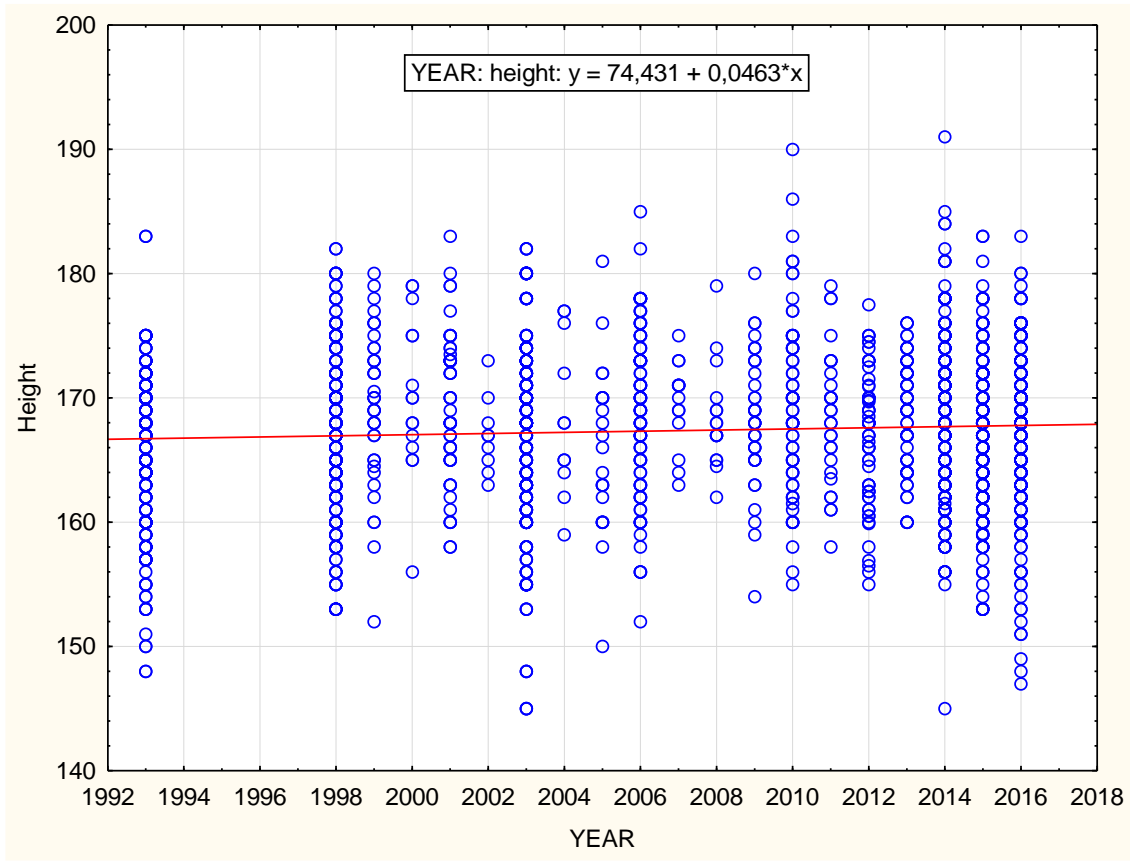

Figure 13. Estimated height increase model in male category

Source: [43]

This results, as well as other works, have shown the existence of a secular trend in Slovakia. We can see the existence of this trend as a global phenomenon. This is also confirmed by the results of various foreign works and research Jelačić et al. (2002), Mokdad, (2002), Baroso et al. (2005), Vígnerová et al. (2006) and Chuan et al. 2010) $[32,26,44,45,46]$. We can see several explanations for increasing body 
dimensions. One of these explanations can be the overall lifestyle, today's way of life, quality, diversity, quantity and ways of eating, as well as health care, sports and other activities. However, other events of the last decade may be the cause of change. The political regime has changed; Slovakia has joined the European Union. In particular, these changes have led to a change in the habits of our population as well as in dining possibilities. The opening of the borders has resulted in a significant globalization of the nation, the population of Slovakia has begun to migrate and interfere with other nations.

Within the presented results, it is necessary to state that the secular trend of the change in the dimensions of the human body has some influence on the dimensions of the furniture and its placement in the living space on the construction of wooden house. In conclusion, we present some examples of what changes in human dimensions can impact on the realization of wooden house. The first are the height of the room ceilings and the subsequent height of the stairs and railing (Figure 14). The authors Bullová, Burák and Kostelný [23] deals with the issue in more details.
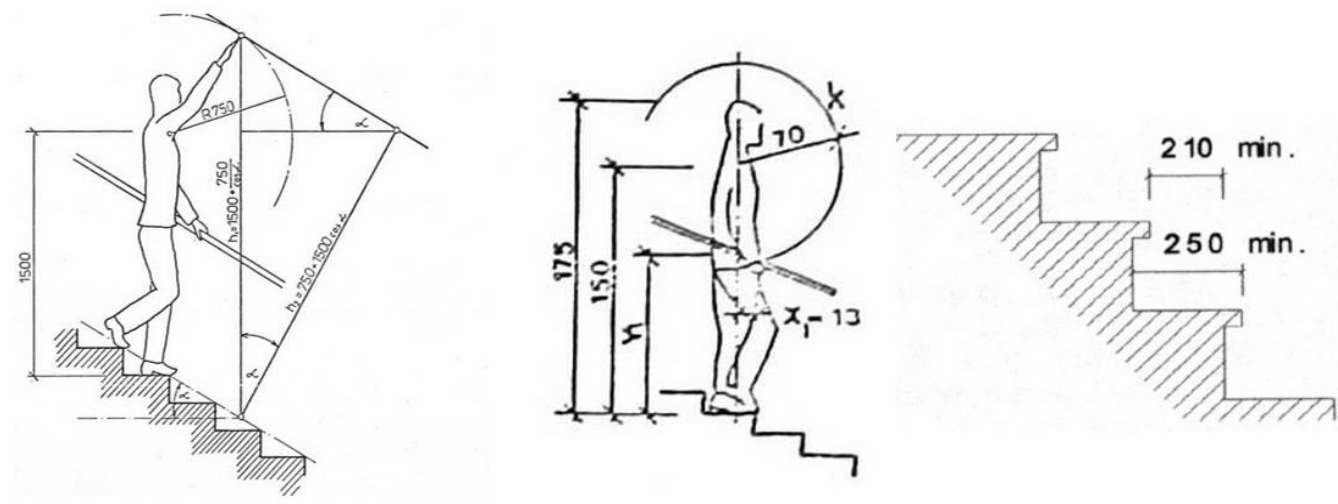

Fig. 14. Examples of construction changes

Source: [23]

The standard size of a human requires a vertical height of $1.90 \mathrm{~m}$ for all activities involving movement while standing. Therefore, any floor area, according to some building codes, that has headroom of more than $1.90 \mathrm{~m}$ is classified as "Usable Space" and can be calculated as part of the minimum required floor area. Bitó [47] in his work states, that "Ancillary Spaces" are usually regarded as less than $1.90 \mathrm{~m}$ in vertical height and are often appropriate for embedded and mobile storage facilities, as well as equipment and furniture placement if they are accessible via a usable space with $1.90 \mathrm{~m}$ headroom or more. These areas can be used when the occupant is not in a standing position (bed, toilet, etc.). "Reduced Utility Spaces" are usually to be found 
where a higher than minimum $(2.20 \mathrm{~m})$ headroom is required (corridors and storage areas). "Full Utility Spaces" refers to areas where headroom of $2.50 \mathrm{~m}$ (fig. 15) may be found as a lower limit for activities where ones hands are raised above head level, including an upper band of space for such uses as the placement of light fittings. This is considered to be lower limit, while the general, average headroom of $2.70 \mathrm{~m}$ is usually adopted for medium-standard homes. Spatial comfort is usually proportional to floor area; therefore, a larger room might have a higher ceiling. Take care not to provide ceilings that are too high in small rooms, since this is often considered confusing.
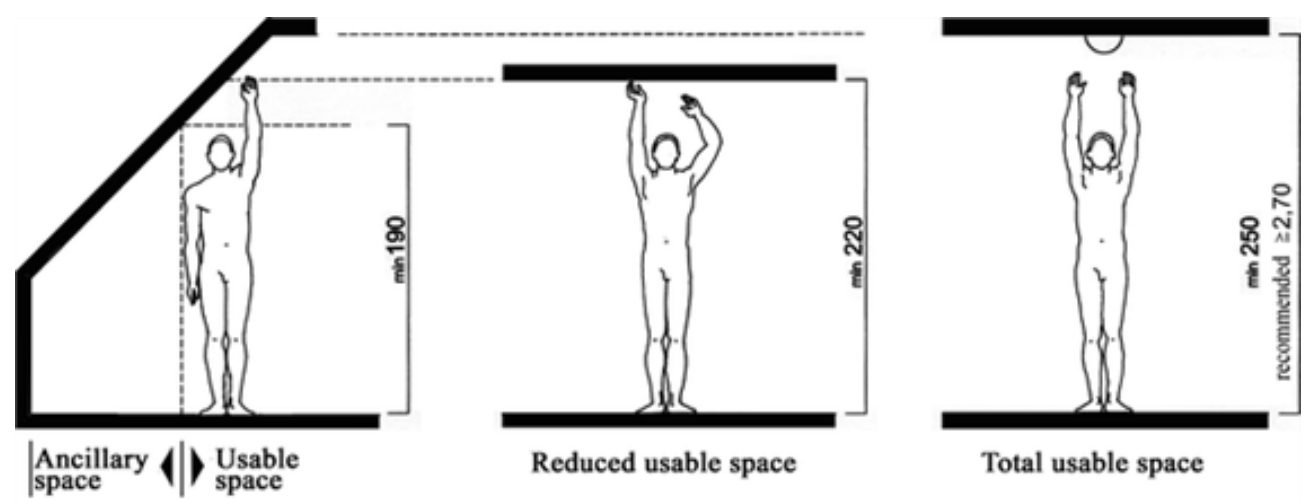

Total usable space

Horizontal ceiling plane preferred in all living areas, kitchen included. Sloping ceilings should be closed at usable height in living areas

Reduced usable space

Horizontal ceiling plane,preferred in all ancillary areas (store,corridors,etc.). Sloping ecilings should be elosed at non-usable height in living areas

Ancillary space

Dimensions should allow for items of furniture to be aceessible and useable in any given area

Fig. 15. Domestic headroom-respective use zones

Source: [47]

Another important aspect is the problem of denying furniture. This issue has been dealt with by Bitó in his study [47].

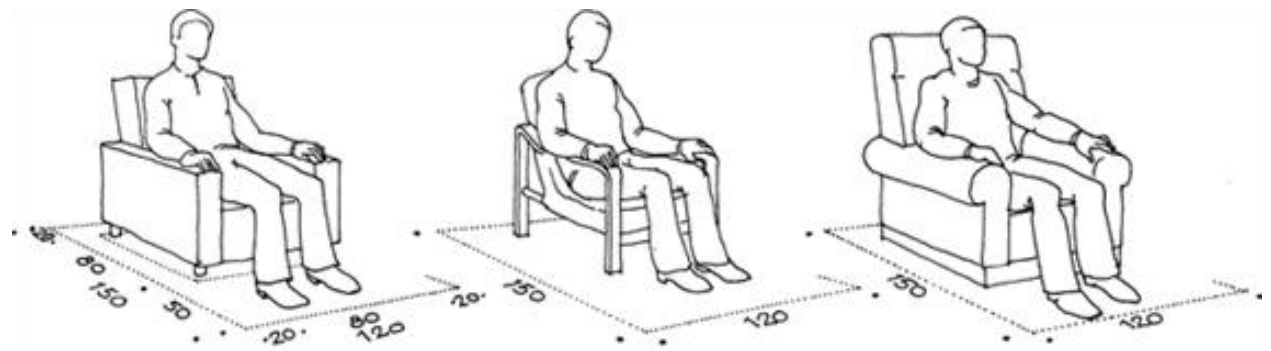

Standard pieces of furniture Small pieces of furniture Slightly larger pieces of furniture

Fig. 16. Various items of furniture - respective use zones

Source: [47] 
He states, that the space required for an individual item of furniture is usually larger than the item itself. When designing the floor plan, this should be taken into consideration. Some furniture is larger than standard size (within reasonable limits), and some smaller, but they still occupies the same furniture zone. (fig. 16). It is also possible to benchmark the size of furnishings at lower or different sizes, so long as one allows for the replacement of furniture over the building's entire lifespan [47]. Important dimensions of most furniture items and their respective use zones are shown in figure 17.

Bitó in his study states that furnishing in some areas may differ significantly from standard values - for example, mobility aids (wheelchairs) or child-careorientated furniture (baby baths and toilet training seats). Standard designs need not take these extremes functions into account; however, if allowed for in the overall development of a project, it might increase a home's value. Larger areas in the home should allow for adaptation and the installation of large-scale items. Multi-unit housing and other forms of repetitive development should allow a leeway of 5-10\% as a starting point when considering possible extremes in the space provided for furniture, fixtures and fittings.

A relatively specific issue is designing kitchen assemblies. Some people spend more time in the kitchen, others less. However, even when preparing food shortly, it is important that you feel comfortable. Apart from appliances, the most important element is the high-quality worktop. They are available in a variety of materials such as wood, marble, artificial material, ceramics and glass. Properly assembling the kitchen unit and choosing its height and especially the worktop you place is greatly appreciated if you spend a lot of time in the kitchen for cooking. With kitchens that are not made to measure, it is more difficult because they cannot be customized to our specific requirements. An inappropriately chosen height of the kitchen line is manifested by back and limb pains. Besides saving health, it is practical if you save time. If there is enough space in the kitchen to make a kitchen according to your expectations, it is very practical if the worktop is placed under the window. This gives you plenty of natural light. It is very practical if there is a jersey near the kitchen worktop where you can rinse or simply put away the used kitchen utensils if necessary. The basic rule for the placement of the worktop is as follows. Experts recommend driving with a simple advice. Parts of the kitchen where the sink is placed should be higher. The parts where I am preparing food and cooking should be placed below. Professionals who produce kitchens say the optimum height for people up to $170 \mathrm{~cm}$ is $85 \mathrm{~cm}$ for the worktop. A worktop of $90 \mathrm{~cm}$ or more is suitable for users with a height of more than $170 \mathrm{~cm}$. Recommendations are presented in Figure 18 [48]. 


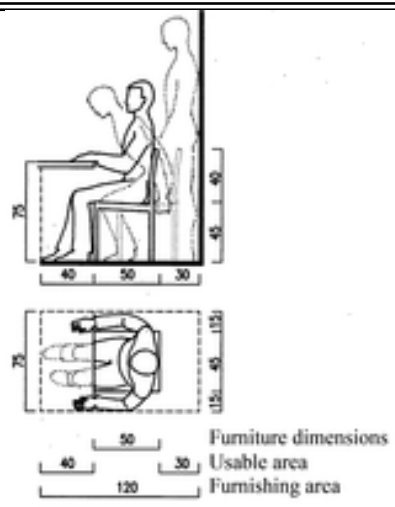

as Chair

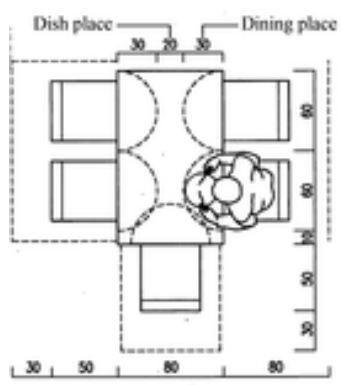

d. $\int$ Dining room furniture
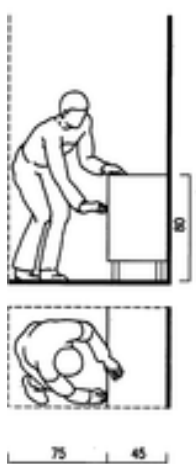

f. $/$ Cabinet
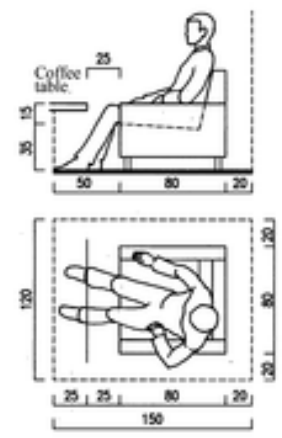

b./ Armchair
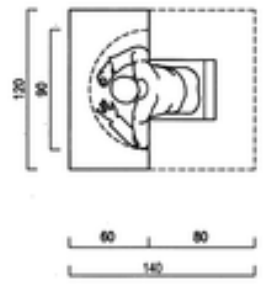

ef Work table

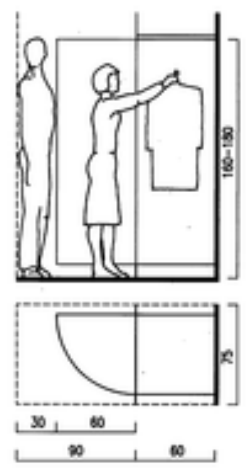

h. Wardrobe

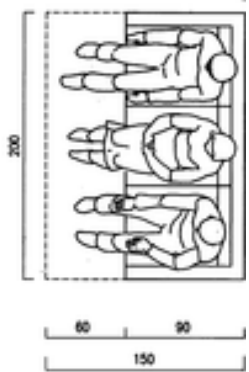

c./Sofa
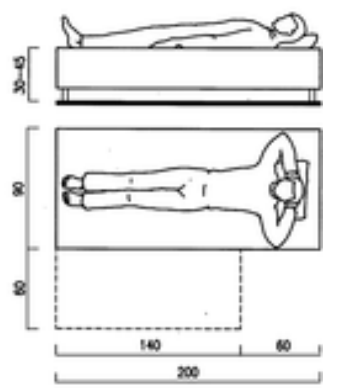

f. $/$ Bed

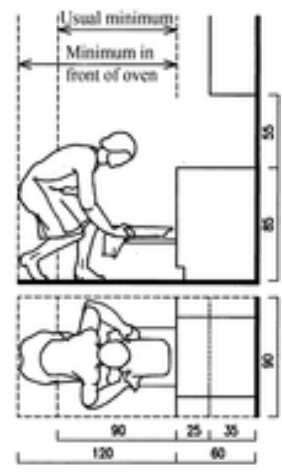

is Kitchen cabinets

Fig. 17. Important spatial requirements for furniture

Source: [47] 

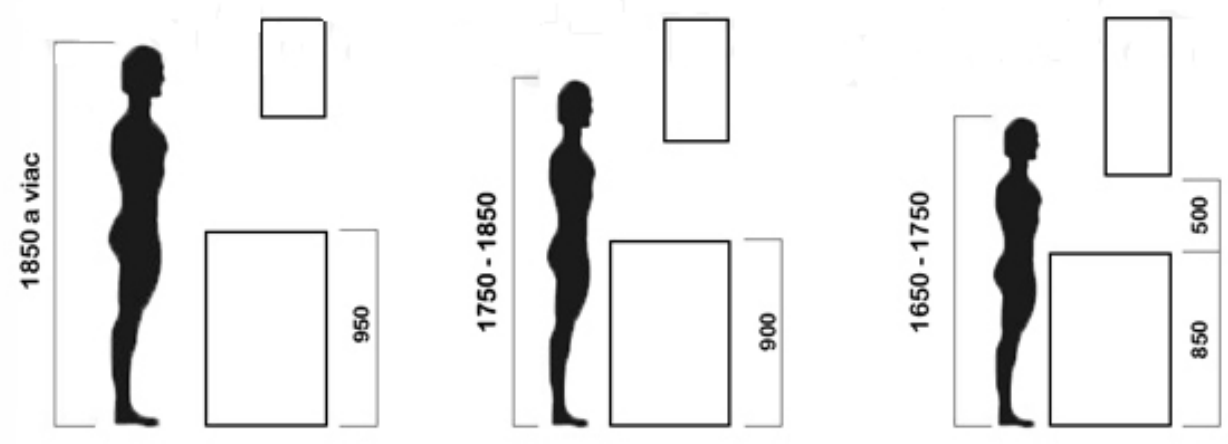

Fig. 18. The correct height of the worktop

Source: [48]

Apart from the height of the kitchen worktop, it is also important to take into account the actual width of the placement. If it is too wide, you need to get rid of it excessively and cause back pain in time. The width should be at least $60 \mathrm{~cm}$. The ideal solution is to place individual work zones in the kitchen with different heights. The cooking zone is better placed $10 \mathrm{~cm}$ lower than the standard worktop (fig. 19). We get a better overview of the pot contents, and in the reduced cooking zone, handling of heavy pots becomes simpler, and long-term mixing is less exhausting. Instead, the washroom is the sink, the height of which should be 10 to $15 \mathrm{~cm}$ larger than the height of the normal worktop. The reason for increasing the height of the wash center is to prevent continuous skidding to the bottom of the sink.

The standard kitchen and work area in the kitchen is $85 \mathrm{~cm}$ and ergonomically suited only to medium height figures. The ideal height of the work surface is when you face the wall, bend the elbow at right angles, and read the height from floor to feet. From this height, then count down $15 \mathrm{~cm}$ to get the desired height of your desktop. 


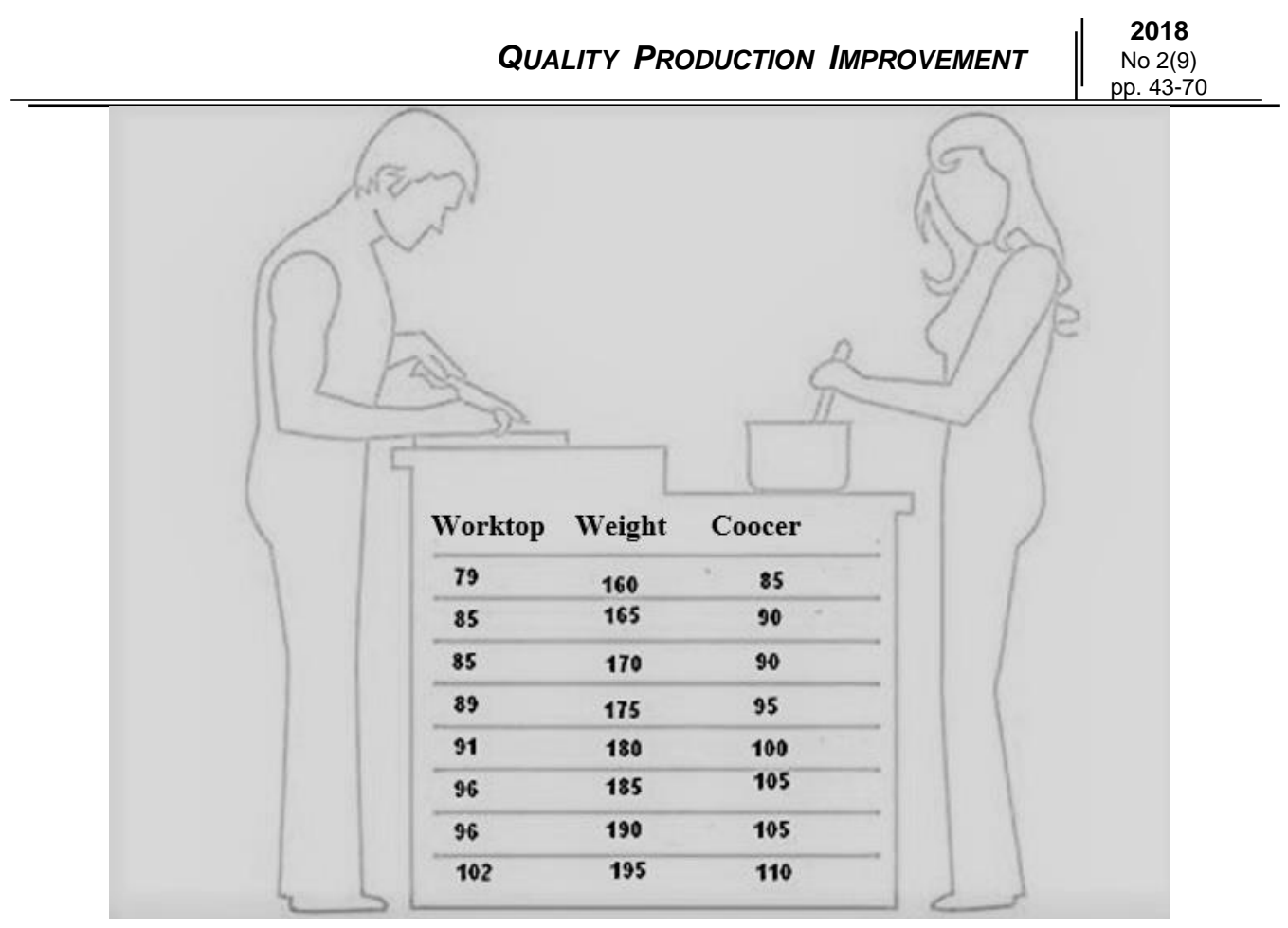

Fig. 19. The correct height of the worktop and coocer

Source: $[49,50]$

According to David Adler [14] and his publication Metric Handbook Planning and design data (2002) is possible to present the sizes of a number of common items of kitchen furniture (fig. 20).

Adler also state that, the most common ailment after the common cold is probably the 'bad back'. Many believe that this can be caused by working on a surface that is too low, causing stooping. Both when standing and sitting to work, it is important that the worktop should be as follows. For manipulative tasks involving moderate degrees of both force and precision: between 50 and $100 \mathrm{~mm}$ below elbow height of the person concerned. For delicate tasks: between 50 and $1000 \mathrm{~mm}$ above elbow height. For heavy tasks, particularly those involving downward pressure on the work piece: between 100 and $300 \mathrm{~mm}$ below elbow height 


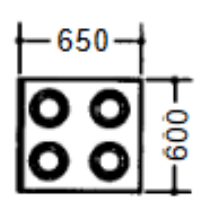

a

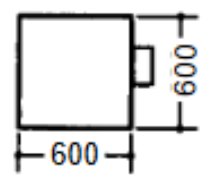

d

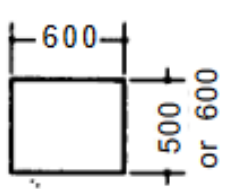

g

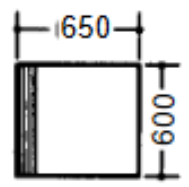

b

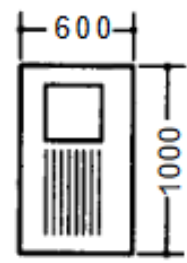

e

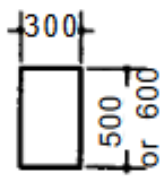

h

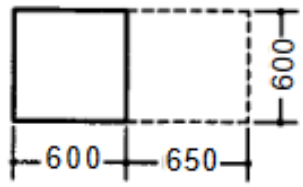

C

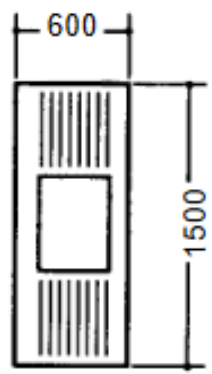

f

2.75 Kitchen: a cooker, b fridge-freezer, c dishwasher, d washing machine, e sink with single drainer, $\mathbf{f}$ sink with double drainer, $\mathbf{g}$ large storage cupboard, $\mathbf{h}$ wall-hung storage cupboard

Source: [14]

Figure 20 Kitchen furniture dimensions

\section{Conclusion}

We can state that based on findings and research, that the current generation of people has significantly higher height and weight proportions. Based on linear regression equations we define the magnitude of secular changes for men and women. The change represents a $1.55 \mathrm{~mm}$ body height increase for men and $0.5 \mathrm{~mm}$ for women per year. Anthropological and ergonomic requirements are crucial in relation to the shape and dimensions of consumer products in many ways. In that section we would like to point out to basic requirements for the internal layout of wooden house from the point of view of ergonomics changes. Secular growth of the anthropometric measurements of the adult population may have an impact at the height of the room ceilings and the subsequent height of the stairs and railing. But also at the spatial 
requirements for furniture, or at the correct height of the worktop and working zones in the kitchen

\section{Acknowledgements}

This research was supported by project of the Ministry of Education, Science, Research and Sport of the Slovak Republic and Slovak Academy of Sciences APVV16-0297 Updating of anthropometric database of Slovak population and project and VEGA No.1/0320/17 Economic and Social Context of European 20/20/20 Targets from the Viewpoint of Economy Low-energy Houses.

\section{Bibliography}

[1] Šuštiaková, M. 2016: Moderné drevostavby - konštrukcie budúcnosti? [online] [cit. 2018-04-02]. Available at: http://mprojekty.sk/blog/modern\%C3\%A9-drevostavbykon\%C5\%A1trukcie-bud\%C3\%BAcnosti.

[2] EN 15459-1:2017: Energy performance of buildings. Economic evaluation procedure for energy systems in buildings. Calculation procedures.

[3] STN EN ISO 6946: 2008 (73 0559), Building components and building elements Thermal resistance and thermal transmittance - Calculation method (ISO 6946: 2008).

[4] Tywoniak, J. 2010. Deklarativní výpočty pro pasivní a nulové domy, 2010. [online] [cit. 2018-04-02]. Available at: http://stavba.tzb-info.cz/normy-a-pravni-predpisynizkoenergeticke-stavby/7456-deklarativni-vypocty-pro-pasivni-a-nulove-domy.

[5] Štefko, J., Potkány, M., Debnár, M. 2017. Impact of selected parameters on the energy performance of buildings. In More wood, better management, increasing effectiveness: starting points and perspective: proceedings of scientific papers. 2017. s. 93-100. ISBN 978-80-213-2761-0. [online] [cit. 2018-04-02]. Available at: URL: http://www.woodema.org/proceedings/WoodEMA_2017_Proceedings.pdf.

[6] Ružiak, I., Igaz, R., Krišt’ák, L., Gajtanská, M. 2017. Heat technique properties of wood based materials in the wooden houses. Monography. Zvolen: TU Zvolen. 105 p. ISBN 978-80-228-2941-0.

[7] Igaz, R. 2014. The efficiency of heat transfer by natural convection according to the heat exchanger surface profile. Monography. Zvolen: TU Zvolen. 198 p. ISBN $978-$ 80-228-2670-9.

[8] Igaz, R. 2010. Heat transfer coefficient - surface temperature relation for verticaly oriented plain plate - air interface by natural convection. In Technické vzdelávanie ako súčast' všeobecného vzdelávania, conference proceedings. Banská Bystrica : Univerzita Mateja Bela v Banskej Bystrici, pp. 210-215. ISBN 978-80-557-0071-7.

[9] International Organization for Standardization. ISO 14040: Environmental Management - Life Cycle Assessment - Principles and Framework; International Organization for Standardization: Geneva, Switzerland, 2006. [Google Scholar]. 
[10]International Organization for Standardization. ISO 14044: Environmental Management - Life Cycle Assessmen - Requirements and Guidelines; International Organization for Standardization: Geneva, Switzerland, 2006. [Google Scholar].

[11]International Organization for Standardization. ISO 14025: Environmental Labels and Declarations - Type III Environmental Declarations - Principles and Procedures; International Organization for Standardization: Geneva, Switzerland, 2006. [Google Scholar].

[12]Cole, T. J., 2000. Secular Trends in Growth. Nutrition Society 59(2): 317-324.

[13] Shah S, Zalawadia A, Ruparelia S, Patel S, Rathod SP, Patel SV. 2011. Morphometric Study of Greater Sciatic Notch of Dry Human Hip Bone in Gujarat Region. 2011.

[14]Adler, D. 2002. Metric Handbook Planning and design data. Reed Educational and Professional Publishing. 784 p. ISBN 0-7506-0899- 4.

[15] Giurazza F, Del Verscovo R, Schena E, et al. 2013. Stature estimation from scapular measurements by CT scan evaluation in an Italian population. Leg Med. Vol.15(4), pp. 202-208.

[16]Torimitsu S, Makino Y, Saitoh H, et al. 2016. Stature estimation from skull measurements using multidetector computed tomographic images: a Japanese forensic sample. Leg Med. Vol. 18. Pp. 75-80.

[17]Kobusingye O. C., Hyder A. A., Bishai D., Hicks R., Mock C., Joshipura M. 2005. Emergency medical systems in low-and middle-income countries: recommendations for action. Bull World Health Organ. Vol. 83 (8), pp. 626-631.

[18]Gharehdaghia, J., Baazmb,M., Ghadipashaa, M., Solhic, S., Toutounchiand, F. 2018. Anthropometric measurements in Iranian men. Journal of Forensic and Legal Medicine. Volume 53, pp 31-34. [online] [cit. 2018-04-02]. Available at: https://doi.org/10.1016/j.jflm.2017.10.013.

[19]Balakumar, R.S. 2010. Perspectives on Anthropometry in Garment Pattern Making. [online] [cit. 2018-04-02]. Available at: http://textilelearner.blogspot.com/2016/03/ perspectives-on-anthropometry-in.html.

[20]Planet Alife. [online] [cit. 2018-04-02]. Available at: http://alife.tuke.sk/kapitola/ 1292/index.html.

[21]Canon of Proportions, Homo Vitruvius [online] http://topobraz.sk/produkt/obraz-naplatne-vitruviansky-muz/ http://topobraz.sk/produkt/obraz-na-platne-vitruvianskymuz/ [online] [cit. 2018-04-02

[22]Cohen, J.L. (2014). Le Corbusier's Modulor and the Debate on Proportion in France . Architectural Histories , 2 (1), Art. 23 . DOI: http://doi.org/10.5334/ah.by.

[23]Bullová, I., Burák, D., Kostelný, V. Typológia budov I+II. Košice: TU Košice. 185 p. [online] [cit. 2018-04-02]. Available at: http://docplayer.gr/43069319-Typologiabudov-i-ii.html. 
[24]Sedmák, R., Hitka, M., 2004. Analýza zmien antropometrických údajov dospelej populácie na území Slovenska. Manažment l'udského potenciálu v podniku. Zvolen, Slovakia, p. 1-7.

[25]Sedmák, R., Hitka, M., 2007. Dynamika zmien vybraných antropometrických znakov populácie Slovenska. HRM\&E. Vol. 3, 24-34.

[26]Barroso, M. P., Arezes, P. M., Costa, L. G., Miguel, A. S. 2005. Anthropometric Study of Portuguese Workers. International Journal of Industrial Ergonomics 35(5): 401-410.

[27]Batogowska, A., Slowikowski, J., 1989. Anthropometric atlas of the Polish population for designer use. Works and Materials, vol. 137. Institute od Industrial Design, Warsaw, Poland.

[28]Bolstad, G., Benum, B., Rokne, A. 2001. Anthropometry of Norwegian Light Industry and Office Workers. Applied Ergonomics 32(3): 239-246.

[29]Iseri, A., Arslan, N. 2009. Estimated anthropometric measurements of Turkish adults and effects of age and geographical regions. International Journal of Industrial Ergonomic 39, 860-865.

[30]Kolena, B., Vondráková, M. 2013. Nitra-Dražovce. Osteologická analýza jedincov zo stredovekého pohrebiska z okolia kostola sv. Michala Archanjela v NitreDražovciach. ISBN 978-80-558-0446-0.

[31] Kothyial, K., Tettey, S. 2000. Anthropometry data of elderly people in Australia. Applied Ergonomics, 20, 329-332.

[32]Mokdad, M., 2002. Anthropometric study of Algerian farmers. International Journal of Industrial Ergonomics 29, 331-341

[33] Scheer, L. 2007. Biometria. Zvolen: Technická univerzita vo Zvolene, 2007. 333 p. ISBN 978-80-228-1723-3.

[34]Debnár, M. Potkány, M. 2016. Potential of wooden houses on the Slovak market. In Microeconomics and management. Current problems. Zagreb: 2016, p. 60-72. ISBN 978-83-65343-02-4.

[35]Debnár, M., Potkány, M. Hitka, M. 2017. Current challenges of the wooden house sector to increase its market potential. In Annals of Warsaw University of Life Sciences. 2017. s. 98--106. ISSN 1898-5912 .

[36]Debnár, M. Potkány, M. Krajčírová, L. 2017. Current situation in the Slovak market in the wooden house sector. In Management and economics in manufacturing: global scientific conference, 5th - 6th October 2017 Zvolen, Slovakia. 2017. s. 82-89. ISBN 978-80-228-2993-9.

[37]https://www.atrium-sk.sk/katalog-domov/jubileum-profi-116 [online] [cit. 2018-0402]

[38]STN 73 0540-2/Z1: 2016. Tepelná ochrana budov. Tepelnotechnické vlastnosti stavebných konštrukcií a budov Čast' 2 Funkčné požiadavky. 
[39]Pelzeter, A.2007. Building optimisation with life cycle costs - the influence of calculation methods", Journal of Facilities Management, Vol. 5 Issue: 2, pp.115-128.

[40]Ozel M. 2012. Cost analysis for optimum thicknesses and environmental impacts of different insulation materials. Energy and Buildings 49 (2012) p. 552-559.

[41]https://www.atrium-sk.sk/vsetko-o-drevostavbach-dom-all-inclusive/ [online] [cit. 2018-04-02].

[42]Debnár, M., Potkány, M. Lorincová, S. 2017. Potentional of affordability assessment of wooden house in Slovakia - case study. In Contemporary problems of economy between theory and business practice in context of diversity. Alba Iulia: 2017, s. 23 40. ISBN 978-606-613-149-0.

[43]Hitka, M., Blašková, S., Sedmák, R., Lorincová, S. 2017. Changes of selected anthropometric dimensions of the adult Slovak population in the context of production management. In Management and economics in manufacturing: global scientific conference, 5th - 6th October 2017 Zvolen, Slovakia. 2017. pp. 174--181. ISBN 97880-228-2993-9.

[44]Jelačić, D., Greger, K., Grladinović, T. 2002. Research on anthropometric characteristics of high school students and ergonomic characteristics of high school furniture. Drvna industrija, 53(2): 99-106.

[45]Vignerová, J., Brabec, M., Bláha, P. 2006. Two centuries of growth among Czech children and youth. Economics and human biology, 4: 237-252.

[46]Chuan, T. K., Hartono, M., Kumar, N. 2010. Anthropometry of the Singaporean and Indonesian populations. International journal of industrial ergonomics, 2010, 40(6): 757-766.

[47]Bitó, J. 2013. Housing design. Budapest University of Technology and Economics, [online] [cit. 2018-04-02]. Available at: http://www.tankonyvtar.hu/en/tartalom/ tamop412A/2011-0055_housing_design/ch01s02.html.

[48]The correct height of the worktop. Available at: http://www.veselebyvanie.sk/ spravna-vyska-kuchynskej-pracovnej-dosky/ [online] [cit. 2018-04-02].

[49]The correct height of the worktop and coocer. Available at: https://www.stave bnik.sk/clanky/aka-je-optimalna-vyska-kuchynskej-linky-.html [online] [cit. 2018-0402].

[50]https://www.modrastrecha.sk/blog/ruthy/album/pomocky-pre-navrhnutie-dokonalejkuchyne

[51]STN EN ISO 6946: 2008

[52] http://www.modernerodinnedomy.sk/archives/684

Date of sending the publication to the Editor: 20.06.2018 The date of the publication's acceptance by the Editorial Board: 23.07.2018 